\title{
Choroba Fabry'ego - długa droga do prawidłowego rozpoznania u 43-letniego chorego „Dr Google” nie zawsze taki zły...
}

\author{
Fabry disease - a long way to diagnosis in 43-year-old patient \\ "Dr. Google" is not always so bad...
}

\author{
Agnieszka Ciba-Stemplewska ${ }^{1}$, Dorota Krzos ${ }^{2}$, Beata Wożakowska-Kapłon ${ }^{3,4}$ \\ ${ }^{1}$ Klinika Chorób Wewnętrznych Wojewódzkiego Szpitala Zespolonego w Kielcach \\ ${ }^{2}$ Zespół Opieki Zdrowotnej w Świętej Katarzynie \\ ${ }^{3}$ Klinika Kardiologii i Elektroterapii Wojewódzkiego Szpitala Zespolonego w Kielcach \\ ${ }^{4}$ Wydział Lekarski i Nauk o Zdrowiu Uniwersytetu Jana Kochanowskiego w Kielcach
}

\section{Streszczenie}

Choroba Fabry'ego (FD) to rzadka choroba spichrzeniowa prowadząca do nagromadzenia w komórkach sfingolipidów wynikającego z braku lub niedoboru enzymu lizosomalnego alfa-galaktozydazy (alfa-GAL). Mimo dość typowego przebiegu sprawia znaczne trudności diagnostyczne. Przerost mięśnia lewej komory - jako fenokopia kardiomiopatii przerostowej - jest bardzo częstym objawem FD i powinien być uwzględniony w różnicowej diagnostyce kardiologicznej. Dostępna w Polsce w ramach programu lekowego enzymatyczna terapia zastępcza FD ma udokumentowaną skuteczność. Rozpoczęcie leczenia na wczesnym etapie opóźnia lub eliminuje objawy, natomiast w przypadku znacznego zaawansowaniu choroby powoduje regresję przerostu mięśnia sercowego. Przedstawiono przypadek chorego, którego lekarze wielu specjalności diagnozowali bez powodzenia przez ponad trzy dekady. Rozpoznanie, dzięki manifestacji skórnej i kardiologicznej, pacjent zawdzięcza swojemu uporowi i wyszukiwarce internetowej.

Słowa kluczowe: choroba Fabry’ego, kardiomiopatia, naczyniaki rogowaciejące, parestezje

Folia Cardiologica 2020; 15, 2: 169-172

\section{Wstęp}

Dziedziczenie choroby Fabry'ego (FD) jest sprzężone z płcią, nie jest jednak typowo recesywne, gdyż mniej nasilone objawy obserwuje się u kobiet. Gen dla enzymu jest zlokalizowany na chromosomie X (Xq22.1). Mutacja w genie (GLA) kodującym alfa-GAL powoduje niedobór lub brak enzymu, czego efektem jest gromadzenie w komórkach glikosfingolipidów (globotriazyloceramidu [GL-3]), co upośledza funkcje narządów [1, 2]. Szacuje się, że występuje
1/40 000 męskich urodzeń [3]. Zależnie od zachowania resztkowej aktywności enzymu manifestacja kliniczna może się różnić. Klasyczne objawy (gdy aktywność enzymu < 1\%) występują u mężczyzn, natomiast u kobiet są mniej nasilone i pojawiają się w późniejszym wieku, co wynika ze stopnia penetracji zmutowanego allelu [3]. Typowe objawy FD pojawiające się już we wczesnym dzieciństwie to bolesne parestezje rąk i stóp, nietolerancja wysiłku, napadowe gorączki i naczyniaki rogowaciejące skóry. Z kolei niewydolność nerek, incydenty naczyniowo-mózgowe, zaburzenia

Adres do korespondencji: lek. Agnieszka Ciba-Stemplewska, Klinika Chorób Wewnętrznych, Wojewódzki Szpital Zespolony w Kielcach, ul. Grunwaldzka 45, 25-736 Kielce, e-mail: aciba@interia.pl 
widzenia oraz przerost lewej komory (LV, left ventricle) jako fenokopia kardiomiopatii przerostowej (HCM, hypertrophic cardiomyopathy) występują po 30. roku życia i są konsekwencją postępu choroby. Jest to typowa klasyczna postać tej jednostki chorobowej. Tak zwany wariant kardiologiczny objawia się tylko przerostem LV (przeważnie koncentrycznym). Rozpoznanie u mężczyzn ustala się na podstawie oceny aktywności alfa-GAL w leukocytach krwi obwodowej oraz w osoczu, natomiast u kobiet na podstawie badania genetycznego $[4,5]$.

Mimo typowych objawów do rozpoznania może minąć wiele lat, jak w omawianym przypadku. Ustalenie rozpoznania jest istotne, ponieważ dla chorych jest dostępny program lekowy z zastosowaniem enzymatycznej terapii zastępczej (agalzydaza alfa i beta).

\section{Opis przypadku}

Do poradni reumatologicznej zgłosił się 42-letni mężczyzna z napadowymi bólami rąk i stóp oraz stanami gorączkowymi występującymi od 6 . roku życia. W badaniu przedmiotowym stwierdzono obecność mnogich naczyniaków skóry okolicy brzucha oraz masywne, ciastowate obrzęki kończyn dolnych (ryc. 1).

W wieku szkolnym, mimo prawidłowego stężenia kwasu moczowego oraz prawidłowej ubogopurynowej diety, rozpoznano u tego chorego dnę moczanową i włączono do leczenia allopurinol. W późniejszych latach zweryfikowano rozpoznanie jako gorączkę reumatyczną i stosowano typową antybiotykoterapię. W okresie dojrzewania pojawiły drobne czerwono-purpurowe zmiany (określone później jako naczyniaki rogowaciejące) oraz nietolerancja upałów i wysiłku fizycznego.

W 20. roku życia chorego diagnozowano w poradni gastrologicznej z powodu bólu brzucha i biegunek. Nie ustaIono przyczyny dolegliwości. W 30. roku życia rozpoznano u niego zakrzepice żylną. W wieku 40 lat, po złamaniu kości śródstopia, pacjent ten zgłosił się na szpitalny oddział ratunkowy (SOR) z powodu duszności spoczynkowej oraz kołatania serca. Na podstawie angiografii tomografii komputerowej klatki piersiowej i wysokiego stężenia D-dimerów rozpoznano wówczas zatorowość płucną (PE, pulmonary embolism). Stwierdzono masywną obustronną PE. Chory został przyjęty na oddział intensywnej opieki kardiologicznej, na którym leczono go heparyną drobnocząsteczkową, a następnie riwaroksabanem w dawce 20 mg. Wynik przeprowadzonej w późniejszym terminie diagnostyki w kierunku trombofilii i klasycznej postaci zespołu antyfosfolipidowego (APS, antiphospholipid syndrome) był negatywny. W przezklatkowym badaniu echokardiograficznym serca uwidoczniono asymetryczny przerost mięśnia LV, z dobrą kurczliwością globalną. Jamy serca były niepowiększone. Wysunięto podejrzenie HCM i zalecono poszerzenie diagnostyki.

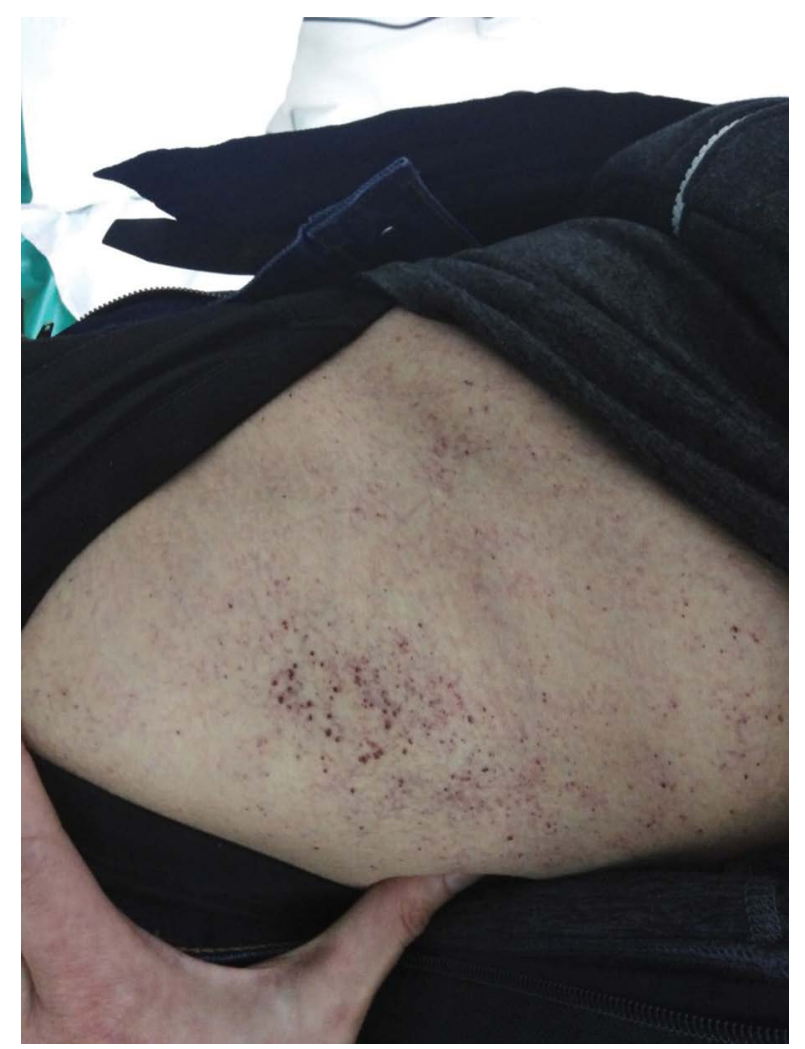

Rycina 1. Naczyniaki skóry

Dwa lata później chorego przyjęto do kliniki chorób wewnętrznych z powodu uszkodzenia wątroby (aktywność aminostransferazy alaninowej [AIAT, alanine aminotransferase] 209 j./l, aktywność aminostransferazy asparginianowej [AspAT, aspartate aminotransferase] $101 \mathrm{j} . / \mathrm{I})$. Pozostałe parametry wydolności wątroby (bilirubina, fosfataza alkaliczna, białko i albumina, układ krzepnięcia) były prawidłowe. Nie stwierdzono przeciwciał przeciw wirusowi wątroby typu $\mathrm{C}(\mathrm{HCV}$, hepatitis $\mathrm{C}$ virus) ani antygenu HBs (hepatitis $B$ surface). W moczu wykazano mikroalbuminurię. Ze względu na narastającą aktywność aminotransferaz chorego, z podejrzeniem polekowego (riwaroskaban) uszkodzenia wątroby, przeniesiono do kliniki chorób zakaźnych. W ramach leczenia przeciwkrzepliwego zastosowano dabigatran. Chory kontynuował diagnostyke HCM w poradni kardiologicznej, gdzie wysunięto podejrzenie amyloidozy. Wykonano obrazowanie serca metodą rezonansu magnetycznego, którego wyniki były następujące: objętość końcoworozkurczowa lewej komory (LVEDv, left ventricular end-diastolic volume) $197 \mathrm{ml}$ (norma 102-235 ml), $111 \mathrm{ml} / \mathrm{m}^{2}$ (norma 53-112 ml/ $\mathrm{m}^{2}$ ) oraz końcowoskurczowa (LVESv, left ventricular end-systolic volume) $61 \mathrm{ml}$ (norma 29-93 ml), $34 \mathrm{ml} / \mathrm{m}^{2}$ (norma 15-45 ml/m²); frakcja wyrzutowa lewej komory (LVEF, left ventricular ejection fraction) 69\%, pojemność minutowa lewej komory (LVCO, left ventricular cordiac output) 7,3 I/min, 
jej wskaźnik (LVCI, left ventricular cardiac output index) 4,1 l/ $\mathrm{min} / \mathrm{m}^{2}$, wymiar końcowrozkurczowy lewej komory (LVEDd, left ventricular end-diastolic diameter) $57 \mathrm{~mm}$ oraz końcowoskurczowy (LVESd, left ventricular end-systolic diameter) $41 \mathrm{~mm}$, przednio-tylny wymiar lewego przedsionka (LAd, left atrial diameter) 35 mm, wskaźnik sztywności lewego przedsionka (LAs, left atrial surface) $24,9 \mathrm{~cm}^{2}$, objętość końcoworozkurczowa prawej komory (RVED, right ventricular end-diastolic volume) $197 \mathrm{ml}$ (norma 47-111 ml), $46 \mathrm{ml} / \mathrm{m}^{2}$ (norma $25-53 \mathrm{ml} / \mathrm{m}^{2}$ ); frakcja wyrzutowa prawej komory (RVEF, right ventricular ejection fraction) 59\%; pojemność minutowa prawej komory (RVCO, left ventricular cordiac output) 6,3 I/min, jej wskaźnik (RVCl, right ventricular cardiac output index) 3,6 I/ $\mathrm{min} / \mathrm{m}^{2}$; wymiar końcowrozkurczowy prawej komory (RVEDd, right ventricular end-diastolic diameter) $51 \mathrm{~mm}$ oraz końcowoskurczowy (RVESd, right ventricular end-systolic diameter) $35 \mathrm{~mm}$, powierzchnia prawego przedsionka (RAs, right atrial surface) $27,2 \mathrm{~cm}^{2}$, masa końcowrozkurczowa lewej komory (LVEDm, left ventricular end-diastolic mass) 182 g (norma 85-181 g), 103 g/m² (norma 46$-83 \mathrm{~g} / \mathrm{m}^{2}$ ); grubość ściany LV w segmentach środkowych: przedni $7 / 16 \mathrm{~mm}$, przednio-przegrodowy $7 / 17 \mathrm{~mm}$, dolno-przegrodowy $10 / 18 \mathrm{~mm}$, dolny $7 / 16 \mathrm{~mm}$, dolno-boczny 6/16 mm, przednio-boczny 6/15 mm; grubość ściany LV nieregularna, odcinkowe pogrubienia niektórych segmentów niespełniające kryterium HCM, najgrubszy segment 5-14 mm oraz segmenty 4., 9., 16.-10. mm (ED); grubość wolnej ściany prawej komory (ED/ES) 4/8 mm; mięsień sercowy bez cech typowych dla amyloidozy ani cech obecności przebudowy włóknistej; mała niedomykalność zastawki aortalnej; poszerzenie układów kielichowo-miedniczkowych obu nerek częściowo objętych badaniem; asymetria grubości częściowo objętych badaniem mięśni szkieletowych klatki piersiowej i kończyn górnych, grubsze po lewej stronie; nioski: mięsień sercowy hiperkinetyczny, odcinkowe pogrubienie ściany LV z granicznymi wartościami dla rozpoznania HCM - obraz może odpowiadać HCM o niepełnej ekspresji fenotypowej.

Przeprowadzono również biopsję tkanki tłuszczowej skóry brzucha. W badaniu histopatologicznym nie uwidoczniono amyloidu.

Konsultujący reumatolog, po wykluczeniu choroby układowej tkanki łącznej oraz dny moczanowej, skierował chorego do poradni chorób rzadkich. Tam wydano opinię, że nie ma podstaw do podejrzewania choroby rzadkiej. Zdeterminowany pacjent przeszukał dostępne w internecie informacje, postawił sobie sam wstępne ropoznanie (FD) i poprosił o pomoc stowarzyszenie chorych („Stowarzyszenia Rodzin z Chorobą Fabry'ego"). Uzyskał istotne dane o miejscach, gdzie należy się zgłosić się w celu wykonania badań biochemicznych i konsultacji .Na podstawie oznaczonej aktywności enzymu, a następnie przeprowadzonych później badań genetycznych(stwierdzono mutacje genetyczną - c.679c>T (p.Arg227Ter) rozpoznano FD i potwierdzono wskazania do enzymatycznej terapii zastępczej. Chory oczekuje na kwalifikację do programu lekowego. Dyskwalifikujące mogą się okazać zawansowane zmiany w ośrodkowym układzie nerwowym.

\section{Omówienie}

Przedstawiono przypadek, który w opinii autorek zasługiwał na omówienie ze względu na bardzo długi okres, jaki upłynął do rozpoznania. Już pojawiające się w dzieciństwie parestezje rąk i stóp mylono z zapalaniami stawów i błędnie oceniano jako dnę moczanową. Moiseev i wsp. [6] podają, że 28/107 pacjentów z FD do czasu prawidłowej diagnozy przez wiele lat rozpoznawano chorobę reumatologiczną [6]. Typowe dla FD zmiany skórne zostały zignorowane przez dermatologów. Nikogo nie zastanowiły, występujące od dzieciństwa, nietolerancja ciepła i wysiłku fizycznego. Dołączenie się objawów ze strony układu sercowo-naczyniowego zapoczątkowało diagnostykę kardiologiczną. Zmiany w obrazie echokardiograficznym są typowe dla FD. Obserwuje się przerost LV (zwykle koncentryczny, a jego ograniczenie jest wyznacznikiem prawidłowej terapii), równolegle towarzyszący (50\%) przerost prawej komory (RV, right ventricle), przerost mięśni brodawkowatych czy poszerzenie aorty wstępującej (rzadko tętniaki). Przedsionki mogą być powiększone i występują łagodne wady zastawkowe, a LVEF jest zwykle zachowana. Czasami widoczny podwójny zarys wsierdzia jest związany z warstwowością gromadzenia glikosfingolipidów [7-10]. Wraz z postępem choroby pojawia się włóknienie LV, ale nie RV.

Obraz echokardiograficzy u chorego sugerował możliwość wystąpienia fenokopii HCM, ale przy narastających ciastowatych obrzękach kończyn dolnych i powtarzających się bólach stawów diagnostykę ukierunkowano na amyloidozę. Wizyta w ośrodku eksperckim nie była pomocna. W wieloletnim procesie diagnostycznym zabrakło nie tylko wiedzy (można to wytłumaczyć rzadkością schorzenia), ale i dyskusji między lekarzami różnych specjalności. Wydaje się, że próba połączenia w całość objawów ze strony wielu narządów oraz licznych, bardzo jednoznacznych, badań obrazowych mogłaby zaowocować trafną diagnozą. Historia ta ilustruje konieczność szerszego i wielodyscyplinarnego spojrzenia na pacjenta - poza ramy jednej specjalizacji.

Wyszukiwarka internetowa, która wielokrotnie bywa źródłem fałszywych informacji, tym razem znakomicie przysłużyła się pacjentowi. 


\section{Abstract}

Fabry disease (FD) is a rare genetic disease that leads to the accumulation of sphingolipids in cells due to the lack or deficiency of the alpha-galactosidase (alpha-GAL), a lysosomal enzyme. It presents a lot of difficulties, despite typical pattern of symptoms. Hypertrophic cardiomyopathy is a very common symptom of FD and should be included in differential cardiological diagnostics. The drug program for patients with Fabry disease, which is avaiable in Poland is an enzyme replacement therapy with proven effectiveness. Starting treatment at an early stage delays or eliminates the symptoms, while at severe disease leads to regression of myocardial hypertrophy. We report a case study of patient who was diagnosed unsuccessfully for over three decades by doctors of many specialties. Diagnosis, thanks to the skin and cardiological manifestation, owes his persistence and Internet search engine.

Key words: Fabry disease, cardiomyopathy, keratomas, paresthesia

Folia Cardiologica 2020; 15, 2: 169-172

\section{Piśmiennictwo}

1. Desnick RJ. Fabry disease, an under-recognized multisystemic disorder: expert recommendations for diagnosis, management, and enzyme replacement therapy. Ann Intern Med. 2003; 138(4): 338-346, doi: 10.7326/0003-4819-138-4-200302180-00014, indexed in Pubmed: 12585833.

2. Hughes DA, Elliott PM, Shah J, et al. Effects of enzyme replacement therapy on the cardiomyopathy of Anderson Fabry disease: a randomised, double-blind, placebo-controlled clinical trial of agalsidase alfa. Heart. 2008; 94(2): 153-158, doi: 10.1136/ /hrt.2006.104026, indexed in Pubmed: 17483124.

3. Kloska A, Tylki-Szymańska A, Węgrzyn G. Lizosomalne choroby spichrzeniowe - ogólna charakterystyka. Post Bioch. 2011; 57: 128-132.

4. Wu JC, Ho CY, Skali H, et al. Cardiovascular manifestations of Fabry disease: relationships between left ventricular hypertrophy, disease severity, and alpha-galactosidase A activity. Eur Heart J. 2010; 31(9): 1088-1097, doi: 10.1093/eurheartj/ehp588, indexed in Pubmed: 20061327.

5. Chaves-Markman ÂV, Markman M, Calado E, et al. GLA gene mutation in hypertrophic cardiomyopathy with a new variant description: is it Fabry's disease? Arq Bras Cardiol. 2019; 113(1): 77-84, doi: 10.5935/abc.20190112, indexed in Pubmed: 31291414.

6. Moiseev S, Karovaikina E, Novikov P, et al. What rheumatologist should know about Fabry disease. Ann Rheum Dis. 2019, doi: 10.1136/ /annrheumdis-2019-215476, indexed in Pubmed: 31040120.

7. Pieroni M, Chimenti C, Cobelli FDe, et al. Fabry's disease cardiomyopathy. JACC. 2006; 47(8): 1663-1671, doi: 10.1016/j.jacc.2005.11.070, indexed in Pubmed: 16631007.

8. Niemann M, Weidemann F. Echocardiography in Fabry disease. Cardiogenetics. 2013; 3(1), doi: 10.4081/cardiogenetics.2013.e3.

9. Weidemann F, Breunig F, Beer M, et al. The variation of morphological and functional cardiac manifestation in Fabry disease: potential implications for the time course of the disease. Eur Heart J. 2005; 26(12): 1221-1227, doi: 10.1093/eurheartj/ehi143, indexed in Pubmed: 15728649.

10. Beer G, Reinecke P, Gabbert HE, et al. Fabry disease in patients with hypertrophic cardiomyopathy (HCM). Z Kardiol. 2002; 91(12): 992-1002, doi: 10.1007/s00392-002-0870-7, indexed in Pubmed: 12490989. 